\title{
Determinants of the Business Performance of Small and Medium Enterprises in an Emerging Market Economy
}

\author{
Peter Ansu-Mensah \\ Sunyani Technical University, Ghana \\ p.ansumensah@stu.edu.gh \\ Paul Adjei Kwakwa \\ Presbyterian University College, Ghana \\ University of Energy and Natural Resources, Ghana \\ pauladkwa@yahoo.com
}

Sandra Nyamedor Teye Maku
Presbyterian University College, Ghana

Purpose: In a developing country such as Ghana, small and medium enterprises (SMEs) have become the fulcrum for economic growth and development. This study aims to examine factors influencing the business performance of SMEs in an emerging market economy.

Study design/methodology/approach: A descriptive survey design was used to collect data from SMEs in the service sectors of retail, hospitality, trade/commerce and manufacturing. The target population were from two municipalities. SPSS 23.0 was used to analyse the data got through the use of the questionnaires.

Findings: The results indicate that governments in emerging economies are not doing enough to help SMEs. Access to credit had aided businesses to acquire modern technologies and raw materials for operation. Many entrepreneurs used their educational level, available business information services and marketing strategies to identify potential customers and to devise better strategies for dealing with their competitors.

Originality/value: The study is the first to conclude that while access to credit aids SMEs' in their operations, it can equally serve as a constraint to their performance. Besides, availability of business information service can help SMEs to gain competitive advantage. Moreover, marketing strategies impact SMEs performance positively. The study will help policy makers and development partners to fashion policies that will enhance the performance of SMEs.

Keywords: SMEs, determinants, business performance, emerging market economy, government, Ghana.

\section{Introduction}

Small and medium enterprises (SMEs) indeed play significant roles in the economy of developed and developing nations (Herr \& Nettekoven, 2018; Khan et al., 2020; Muzenda, 2014). The SMEs capability to provide employment to boost an economy makes it an important sector that attracts various governments worldwide, and more specifically, in emerging/developing economies (Anigbogu, Onwuteaka, Edoko, \& Okoli, 2014; Keskin, Sentürk, Sungur, \& Kiris, 2010; Laurențiu, 2016; Zdraveski, Janeska, Sotiroski, \& Kukunoski, 2018). To understand the determinants of the performance of SMEs will not only assist individuals and businesses to be profitable, but also help in the socio-economic development of most countries thereby enabling them to generate jobs for the citizenry (Herr \& Nettekoven, 2018; Keskin et al., 2010; Zdraveski et al., 2018).

There are various definitions of SMEs and it is noteworthy that these definitions have come about due to the economic sizes of nations across the world. Thus, while many countries use the number of employees/workforce as a yardstick in the attempt to define SMEs, others rely 
on turnover (Keskin et al., 2010). According to Rasoli \& Mirza (2019:99), the World Bank Group currently defines SMEs as "encompasses enterprises with up to 300 employees and total annual sales of up to US\$15 million”. Equally, the body that regulates SMEs in an emerging economy Ghana, the National Board for Small Scale Industries (NBSSI) defines SMEs as businesses that are capable of employing more than 9 persons with fixed assets of 10 million Ghana cedis (Abor \& Quartey, 2010; Akorsu \& Agyapong, 2012; Domeher, Musah, \& Hassan, 2017). It is worth emphasizing that what is common about the above definitions relate to the number of people employed. Consequently, the NBSSI working definition has been adopted for this study because it is the body that regulates SMEs activities in Ghana.

The important roles performed by SMEs in both developed and developing economies are enormous. SMEs are gradually being acknowledged as dynamic drivers of economic growth and development in Africa as well as globally (Abisuga-oyekunle, Patra, \& Muchie, 2020; Afolabi, 2015). SMEs help with the social and economic development of a country which includes employing people, alleviating poverty (Akorsu \& Agyapong, 2012; Ibrahim \& Mustapha, 2019; Mutandwa, Taremwa, \& Tubanambazi, 2015b; Muzenda, 2014), and development of human resource and contribution to gross domestic product (Akorsu \& Agyapong, 2012; Mutandwa et al., 2015b; Nunkoo et al., 2020). The economic growth in Germany, China, Japan, Taiwan, Malaysia, Nigeria, Kenya and many others are considerably impacted by SME activities. With regard to SMEs contribution to GDP, Agyapong, Agyapong, \& Poku (2017) and Peris, Supian, Hasanat, \& Hossain (2020) revealed the following; Germany (75\%), China, (60\%), Japan (50\%) and Bangladesh (25\%).

Conversely, despite their significance and contribution to the development of countries, SMEs are faced with myriad of problems among which are insufficient funding or lack of credit, managerial skills deficiencies, lack of raw materials, managerial inadequacies and bigger transaction charges (Abisuga-oyekunle et al., 2020; Akorsu \& Agyapong, 2012; Mutandwa et al., 2015b; Nunkoo et al., 2020).

Ghana is an emerging country in sub-Saharan Africa (SSA) region with a projected population of 30.42 million, with about 12.84 million as its total workforce (Ansu-Mensah et al., 2021; Ghana - Total Labor force, 2019; World Population Review, 2019). In Ghana, SMEs have become the fulcrum for growth and development. According to scholars such as, Abor \& Quartey (2010); Adongo, Atugeba, \& Insah (2020); Sarbah \& Wen (2014) and Setsoafia, Sarpong, \& Kwadzo (2013), SMEs make an estimated contribution of $60-70 \%$ to Ghana's GDP and therefore, they generate so much revenue annually to assist the government of Ghana.

Outstandingly, the crucial role played by SMEs in the development of Ghana's economy cannot be overstated. It is no wonder that the government of Ghana has fashioned policies to support SMEs so that they can continue to contribute their quota to the economic development of the country thereby performing starring roles such as; offering employment, poverty reduction, human resource development, and contributing to GDP. In spite of the foregoing government efforts, various SMEs are not able to improve on their performances and that their rate of failure is on the high. Furthermore, most research on the performance of SMEs has been done in developed economies. Therefore, a study on factors influencing the growth and business performance of SMEs in an emerging economy is an area of necessity and worth studying in the small business literature.

Against this backdrop, the study aims to examine the factors influencing the business performance of SMEs in an emerging market economy. Consequently, the study will seek to answer the research question: what factors influence the business performance of SMEs in Kwahu East and Kwahu West Municipalities of the Eastern Region in Ghana? 
The important contributions of this research will be as follows: first, the study's findings will be vital to owners of SMEs in Ghana as well as other emerging market economies as the findings would support them to identify and cope with factors that influence the business performance of SMEs. Second, this study adds to the literature by considering factors that impact SMEs' performance in emerging economies. Third, the study will help policy makers and development partners to fashion policies that will enhance and better the performance of SMEs. Again, the findings can be used by the government of Ghana and other developing and developed nations to advance their socio-economic development programs thereby helping them achieve their strategic visions in the foreseeable future. Moreover, development partners will equally find this study useful in developing programs for funding of activities for improving the performance of SMEs. Furthermore, this study will contribute to the scholarly dialogue regarding SMEs in emerging economies and will be important to future researchers who may want to use it as a reference document.

The rest of this paper is structured as follows. The next section is on literature review which culminates in constructing the research model. The research methodology, results, discussions and conclusions follows subsequently.

\section{Literature Review}

\section{Measuring Business Performance of SMEs}

Business performance is undeniably open to different dimensions and interpretations in the business arena. These diverse dimensions of the concept business performance comprise employee numbers, profitability, and sales (Muzenda, 2014). Performance measurement is the assessment of the extent to which businesses could be managed and what they offer to their customers and interested parties (Aziz \& Mahmood, 2011; Mwihaki, 2015; Oyedele et al., 2014; Vuolle, 2011). Researchers such as, (Bhagwat \& Sharma, 2007; Mwihaki, 2015) have argued that SMEs can measure their business performance through the use of financial and nonfinancial processes which is of three perspectives (i.e., financial perspective, internal business perspective and customer perspective).

\section{Financial Perspective}

The performance of many organizations is measured on the basis of the firms' market value, liquidity, investments, and profits (Neely, 2002; Neely \& Austin, 2004). As organizations aim to be profitable, it behoves on them to ensure that the goals they set are achieved. If they succeed, then they are adjudged to be a performing business else the vice versa holds (Neely \& Austin, 2004).

\section{Internal Business Perspective}

This perspective works on the premise that organizations should display both efficiency and effectiveness in their day-to-day activities in order to please their customers (Yang \& Islam, 2012). This, in so doing, enables the businesses to provide goods or services that customers will be satisfied with while the company too makes profit.

\section{Customer Perspective}

As one of their main aims, SMEs satisfy their customers through the provision and delivery of products or services on timely basis (Parry, Jones, Rowley, \& Beata, 2012; Vuolle, 2011). Achieving such an aim suggest that the organization's performance is high, whereas, not being able to realize that aim implies that the performance level has been lowly (Mwihaki, 2015; Otero, Gallego, \& Pratt, 2014; Parry et al., 2012). 


\section{Determinants Influencing the Performance of SMEs}

\section{Government policies and regulations on the performance of SMES}

It is imperative for governments that intend to promote small enterprises to scrutinize the effect of its rules and procedures on small companies (Matovu, 2011). If proper care is not taken, policy initiatives of governments might destroy the small businesses. Though it is a known fact that SMEs role in the development of any economy is huge, yet little has been done to assist them perform such significant roles. In fact, mention can be made of countries such as India, which has come out with favourable actions to promote SMEs so that they can perform their duties effectively to aid the economy (Vettriselvan \& Sathya, 2018; Xavier \& Gomez, 2018). The government of Ghana also came up with reforms in 1992 to strengthen the private sector (Aryeetey \& Ahene, 2005)

\section{Access to credit on the performance of SMEs}

Among the various limitations that SMEs encounter, finance is the overwhelming imperative of all. Inability to get funds/credit for raw materials purchases is really the sole problem of SMEs (Kayanula \& Quartey, 2000). In their study on SMEs, Aryeetey \& Ahene, (2005) revealed that $38 \%$ of SMEs identified funding as the main restriction and that SMEs have restricted admittance to capital markets. In sub-Sahara Africa, several small businesses do not make it past the initial stage because of governments and commercial banks inability to grant them credits (Abor \& Biekpe, 2007; Kayanula \& Quartey, 2000; Opoku-Afriyie, 2019). According to Kayanula and Quartey, (2000); and Opoku-Afriyie, 2019), the issue of financing facing small firms have fundamentally blocked the role these SMEs can play in socio-economic developments.

\section{Availability of business information service on SMEs performance}

It is reported that in order for SMEs in emerging market nations to promote sustainable levels of development, availability of business information services should be considered by governments and business services suppliers (Ngetich \& Kithae, 2020; Ojo, Akinsunmi, \& Oluwatimilehin, 2015). Numerous SMEs in developing countries work in situations where information is inadequate mainly because of insufficient business bolster services and lowly information technological foundations (Adeola, 2014). According to Kauffmann, (2005), access to information has in a way not been given a much consideration as limitations to the improvement in SMEs performance. In advanced nations, SMEs have easy access to business information services because of well-developed ICT infrastructure (Ganbold, 2008), while in emerging market economies, numerous difficulties exist with respect to ICT infrastructure, equipment and programming. And this has increased the problems for the SMEs sector especially in the area of business information services (Mutandwa et al., 2015b).

\section{Entrepreneurs' characteristics on the performance of SMEs}

Numerous studies have looked at the connection between the attributes of the entrepreneur and the firm's performance (Islam, Khan, Obaidullah, \& Alam, 2011; Oyedele et al., 2014; Širec \& Močnik, 2010). Storey (2011, p.307) has concluded that gender, age, education, motivation and past work experience are the elements which will probably influence the performance of the firm. Regarding the entrepreneur's gender, Opoku-Afriyie, (2019) and Philip (2010) announced that some SMEs firms that are led by men will undoubtedly perform superior to those by women. With the age of the entrepreneur, the more youthful the entrepreneur is the more energetic and committed to the work and will likely accept risk than older entrepreneurs. 
With regards to education, the fact that a business owner has higher educational levels may inspire growth and the firm's performance (Neneh, 2011).

Therefore, Gunawan, Jacob, \& Duysters (2016) reported that such people might not be qualified to perform management roles for the businesses. It is no wonder that (Ibrahim \& Mustapha, 2019; Mutandwa et al., 2015b; Muzenda, 2014) did not find any correlation between previous SMEs experiences and firm's performance. Similarly, experience impact the performance of the firm (Barreira, 2004; Pena, 2004; Peña, 2002; West \& Noel, 2009).

\section{Marketing strategies impact on the performance of SMEs}

It is important to note that marketing strategies indeed influence the business performance of SMEs (Ibrahim \& Mustapha, 2019; Mutandwa et al., 2015b; Muzenda, 2014; Tang, Wang, \& Zhang, 2007). Marketing strategies stipulate passages that marketing departments in firms take to realize their marketing aims (Wilson \& Gilligan, 2005). These strategies are the various business activities that are planned and produced and are related to pricing and the eventual formation of SMEs competitive policies (Dzisi \& Ofosu, 2014; Keh, Nguyen, \& Ng, 2007). Marketing strategies aid in the achievement of business successes, hence, its influence on performance of SMEs cannot be over-emphasized (Amin, 2021). How firms frame and implement their marketing strategies impact the extent to which they can be successful or unsuccessful (Finoti et al., 2017). It is therefore necessary for various educational campaigns to be developed so as to encourage the implementation of the marketing strategies (Tang et al., 2007).

With regard to the reviewed literature above, a model is proposed with the variables: government policies and regulations, access to credit, availability of business info, entrepreneurs' characteristics, marketing strategies and factors influencing SMEs performance. See Figure 1.

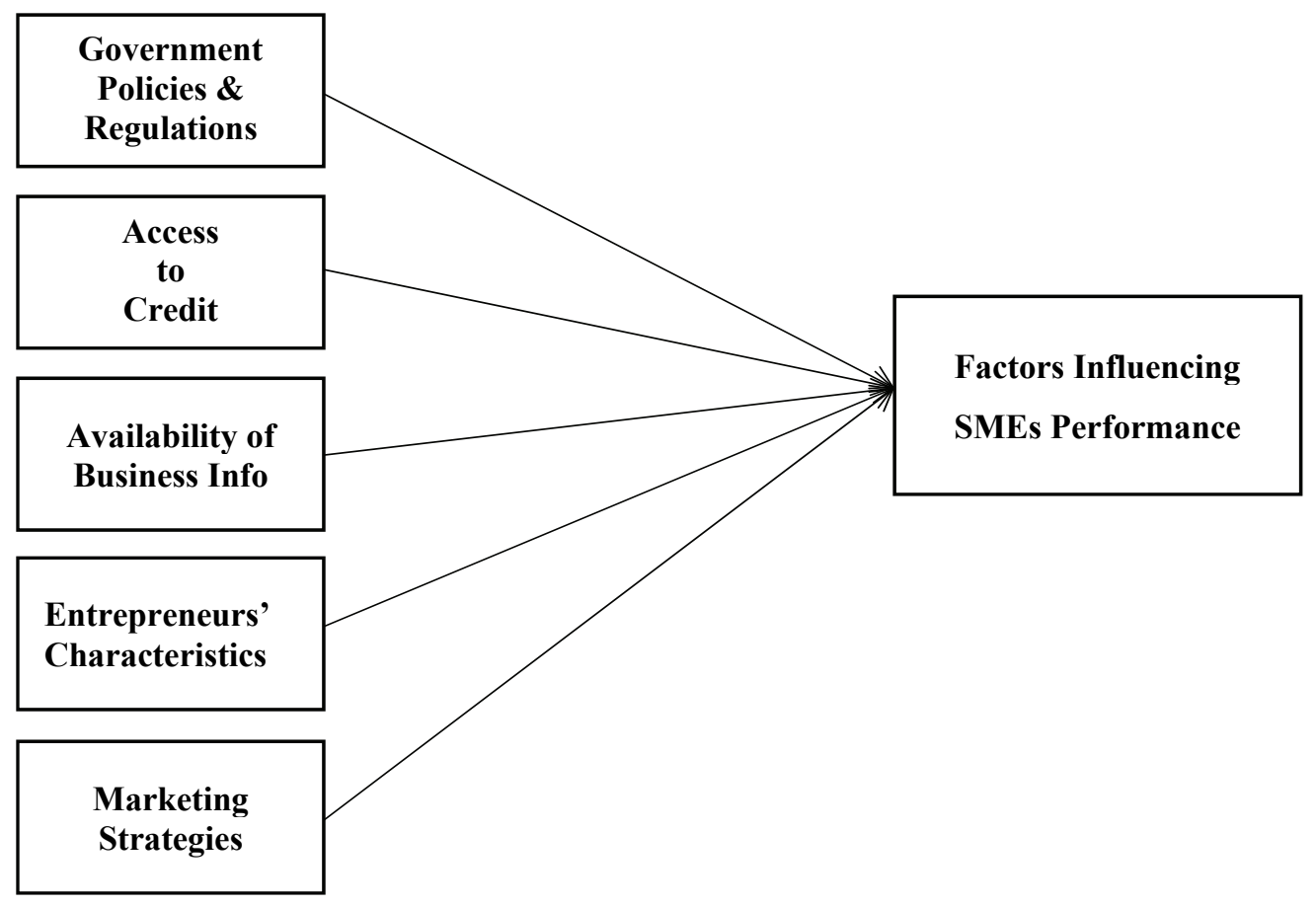

Figure 1: Research Model 


\section{Methodology}

\section{Research Design}

A descriptive survey design was used in this study to examine the determinants of business performance of SMEs in an emerging market economy such as Ghana. Descriptive surveys enable the collection of data from big samples and for generalizations to a bigger population and thus help in the analysis and determination of individuals' views, behaviours and attitudes (Creswell, 2009; Leavy, 2017).

\section{Sample and Sample Size}

The target population consisted of SMEs working in Kwahu West Municipal Assembly with its capital at Nkawkaw and Kwahu East District with the district capital at Abetifi. The sample was chosen from the manufacturing, retail (trade \& commerce), hospitality and agriculture informal service sectors. This population is chosen because they are from the most business/commercial areas in the Eastern region of Ghana. It is notable that there was no precise number for the population of SMEs since most of the businesses in the two districts were not registered. Therefore, in this study, the researchers used convenience sampling to select the sample size of fifty-five SMEs, thirty from Kwahu West district and twenty-five from Kwahu East district. Besides, the respondents in the study were carefully chosen due to their readiness and availability. Moreover, the respondents' ages extended from 20 to 61 plus.

\section{Procedures}

Convenience sampling was used to select the respondents of SMEs in the service sectors of retail, hospitality, trade or commerce, and manufacturing. It is worth mentioning that convenience sampling was used because there were no official records of the population of SMEs, as most of these SMEs prior to their setting up had not registered with the two district assemblies. However, further enquiries from the district assemblies revealed that the assemblies' local instruments enjoin all SMEs to register before the start of their businesses. Initially, 80 structured questionnaires were given out but we received 55 usable ones and this represented a response rate of $68.8 \%$ (see Table 4.1 ).

\section{Measures}

The measurement items used in the study were 5-point Likert type scale which ranged from 1: strongly disagree, 2: disagree, 3: neutral, 4: agree and 5: strongly agree. Using the above scale, respondents were requested to point out their agreement levels on the questionnaire items. The variables were; government policies and regulations, access to finance, availability of business information, entrepreneur's characteristic and marketing strategies and performance of SMEs.

\section{Data analysis}

The statistical package for social science (SPSS 23.0) was used to analyse the data got through the use of the questionnaires. .

\section{Findings and Discussion}

\section{Findings}

\section{Demographic profile of respondents}

In the analysis of the demographics respondents' gender, age, level of education and nature of business have been discussed below. 
Table 4.1: Demographic profile of respondents

\begin{tabular}{llrr}
\hline Item & Category & Frequency & Percentage \\
\hline Gender & Male & 33 & 60 \\
& Female & 22 & 40 \\
\hline Age & $20-30$ & 24 & 43.6 \\
& $31-40$ & 12 & 21.8 \\
& $41-50$ & 8 & 14.5 \\
& $51-60$ & 8 & 14.5 \\
& $61+$ & 3 & 5.5 \\
\hline Education background & Junior High School & 3 & 5.5 \\
& Senior High School & 22 & 40.0 \\
& Tertiary & 30 & 54.5 \\
\hline Nature of business & Beauticians & 9 & 16.4 \\
& Restaurants & 13 & 23.6 \\
& Hotels & 12 & 21.8 \\
& Fashion designers & 9 & 16.4 \\
& Grocery shops & 12 & 21.8 \\
\hline
\end{tabular}

Out of the 55 sampled respondents, $22(40 \%)$ were females, while $33(60 \%)$ were males. Again, Table 4.1 illustrates the ages of the respondents. Twenty-four $(43.6 \%)$ respondents were between the ages of 20-30 years, $12(21.8 \%)$ were between $31-40$ years, $8(14.5 \%)$ were between the ages of 41-50 years, another $8(14.5 \%)$ fell between 51-60 years and $3(5.5 \%)$ were between the ages of 61 and above. The highest percentages of respondents were those between the ages of 20-30 years whereas the lowest percentages of respondents were between $61+$ which again suggests that these SME businesses are full of the youth of the country.

With reference to the educational backgrounds of respondents, majority had tertiary education $(54.5 \%)$ and the lowest qualification was basic education. With regards to the nature of business of the respondents, $9(16.4 \%)$ were beauticians, $13(23.6 \%)$ were into restaurant business, 12 $(21.8 \%)$ were in hotel services, $9(16.4 \%)$ were fashion designers and $12(21.8 \%)$ were grocery shop owners.

\section{Influence of Government Policies and Regulations on the Performance of SMES}

Respondents were asked to indicate the degree to which they agree with statements below that highlight government policies and regulations influence on SMEs performance.

Table 4.2: Government Policies and Regulations Influence on SMEs Performance

\begin{tabular}{lrr}
\hline Do you think the local assembly is doing anything special to help the SMEs & Frequency & Percentage \\
in your locality? & 11 & 20.0 \\
\hline Yes & 44 & 80.0 \\
No
\end{tabular}

Looking at Table 4.2 above, the findings indicate that the government is not really doing enough to support the SMEs. Again, the findings indicated that it is not just the government who is not helping but that most SMEs are also not playing their part to help.

\section{Influence of Access to Finance on the Performance of SMEs}

Respondents were asked to indicate the degree to which they agree with statements below which focus on how access to credit influences SMEs performance.

Table 4.3: Access to Finance on the Performance of SMEs

\begin{tabular}{llllll}
\hline Statement & $\mathrm{SD}$ & $\mathrm{D}$ & $\mathrm{N}$ & $\mathrm{A}$ & \multicolumn{1}{l}{$\mathrm{SA}$} \\
& $\mathrm{F}(\%)$ & $\mathrm{F}(\%)$ & $\mathrm{F}(\%)$ & $\mathrm{F}(\%)$ & $\mathrm{F}(\%)$ \\
\hline $\begin{array}{l}\text { Access to finance has aided my business acquire } \\
\text { certain raw materials needed for operation. }\end{array}$ & $4(7.3)$ & $10(18.2)$ & $17(30.9)$ & $19(34.5)$ & $5(9.1)$ \\
$\begin{array}{l}\text { My business is able to pay off its workers due to } \\
\text { access to finance. }\end{array}$ & $3(5.5)$ & $8(14.5)$ & $14(25.5)$ & $23(41.8)$ & $7(12.7)$ \\
\hline
\end{tabular}




\begin{tabular}{llllll}
\hline $\begin{array}{l}\text { My business has acquired modern technologies } \\
\text { which have affected its production positively due }\end{array}$ & $5(9.1)$ & $12(21.8)$ & $9(16.4)$ & $22(40,0)$ & $7(12.7)$ \\
$\begin{array}{l}\text { to access to finance. } \\
\begin{array}{l}\text { Access to finance has helped my business expand } \\
\text { due to new strategies adopted. }\end{array}\end{array}$ & $3(5.5)$ & $18(32.7)$ & $18(32.7)$ & $12(21.8)$ & $4(7.3)$ \\
\hline
\end{tabular}

The above table indicates that $7.3 \%$ strongly disagreed, $18.2 \%$ respondents disagreed, $30.9 \%$ were neutral, $34.5 \%$ agreed and finally $9.1 \%$ strongly agreed on the fact that access to finance had aided their businesses in acquiring raw materials for operation. Also, businesses were able to pay their workers due to access to finance. This is illustrated that $23(41.8 \%)$ and $7(12.7 \%)$ agreed and strongly agreed respectively to the statement. Moreover, on whether acquiring or purchasing modern technologies has affected SMEs positively and hence improved their performance level due to access to finance; the result showed that just few businesses had access to finance to acquire certain technologies that helped improved their production. Furthermore, majority of respondents $(32.7 \%)$ agreed that access to finance has helped their businesses expand due to new strategies adopted, but further $36.4 \%$ remained neutral.

\section{Influence of Availability of Business Information Service on SMEs Performance}

The study tries to find the limit to which respondents were in agreement with the statements on the influence of business information services availability on SMEs Performance. The result is indicated below:

Table 4.4: Availability of Business Information on the Performance of SMEs

\begin{tabular}{llllll}
\hline Statement & $\mathrm{SD}$ & $\mathrm{D}$ & $\mathrm{N}$ & $\mathrm{A}$ & $\mathrm{SA}$ \\
$\mathrm{F}(\%)$ & $\mathrm{F}(\%)$ & $\mathrm{F}(\%)$ & $\mathrm{F}(\%)$ & $\mathrm{F}(\%)$ \\
\hline $\begin{array}{l}\text { Business information helps me devise better } \\
\text { strategies for dealing with competitors. }\end{array}$ & $2(3.6)$ & $7(12.7)$ & $14(25.5)$ & $26(47.3)$ & $6(10.9)$ \\
$\begin{array}{l}\text { With business information, my business is } \\
\text { able to identify potential customers and }\end{array}$ & $1(1.8)$ & $5(9.1)$ & $11(20.0)$ & $24(43.6)$ & $14(25.5)$ \\
develop a business relationship with them. & & & & \\
$\begin{array}{l}\text { An information in my business helps in } \\
\text { decision making and solving problems. }\end{array}$ & $5(9.1)$ & $13(23.6)$ & $23(41.8)$ & $14(25.5)$ \\
$\begin{array}{l}\text { Information on strength, weakness, } \\
\text { opportunity and threat about my business has } \\
\text { helped me to know the internal and external } \\
\text { position of the business hence; I am able to } \\
\text { secure my business. }\end{array}$ & & $2(3.6)$ & $11(20.0)$ & $26(47.3)$ & $14(25.5)$ \\
\hline
\end{tabular}

Many respondents agreed, 26 (47.3\%), and strongly agreed, 6 (10.9\%), that businesses operate with information to help devise better strategies for dealing with their competitors. Also, access to information has helped businesses identified potential customers and developed a business relationship with them. This basically shows that majority of the SMEs agreed to the fact that, having information about their customers is one of the key things they need not miss when it comes to business. This helps them identify what their customers' need. With this, they are able to establish a good relationship with them and do not lose them to other competitors. With regards to whether business information has aided in decision making and solved problems, respondents agreed (41.8\%) and strongly agreed $(25.5 \%)$. The respondents further indicated that the source of business information that helped in decision making in the business were internet, suppliers, customers, newspapers and magazines and seminars. Similarly, Table 4.4 shows that many SME firms agreed that strength, weakness, opportunity and threats have helped them to identify and understand key issues affecting businesses. In brief, they are able to understand their businesses better, address weaknesses that may arise, deter threats, identify and capitalise on opportunities and take advantage of their strengths to develop business goals and strategies for achieving them. 


\section{Influence of Entrepreneurs Characteristics on the Performance of SMES}

Various statements on how entrepreneurs' characteristics impact the performance of SMEs were asked. Below are the responses that were gathered.

Table 4.5: Entrepreneurs Characteristics on the Performance of SMEs

\begin{tabular}{|c|c|c|c|c|c|}
\hline Statement & $\begin{array}{l}\text { SD } \\
\mathrm{F}(\%)\end{array}$ & $\begin{array}{l}\mathrm{D} \\
\mathrm{F}(\%) \\
\end{array}$ & $\begin{array}{l}\mathrm{N} \\
\mathrm{F}(\%) \\
\end{array}$ & $\begin{array}{l}\mathrm{A} \\
\mathrm{F}(\%) \\
\end{array}$ & $\begin{array}{l}\text { SA } \\
\mathrm{F}(\%) \\
\end{array}$ \\
\hline $\begin{array}{l}\text { Being persuasive in my business has helped me } \\
\text { reach out to greater number of customers and } \\
\text { that has increased my sales for the last four } \\
\text { months. }\end{array}$ & $1(1.8)$ & $7(12.7)$ & $18(32.7)$ & $24(43.6)$ & $5(9.1)$ \\
\hline $\begin{array}{l}\text { My business has been running successfully due } \\
\text { to the passion and confidence I have in it. }\end{array}$ & $1(1.8)$ & 0 & $12(21.8)$ & $30(54.5)$ & $12(21.8)$ \\
\hline $\begin{array}{l}\text { Past experience has helped me do things better } \\
\text { in my business. }\end{array}$ & $1(1.8)$ & $2(3.6)$ & $12(21.8)$ & $19(34.5)$ & $21(38.2)$ \\
\hline $\begin{array}{l}\text { Having a strong vision or being goal oriented } \\
\text { has helped me achieve greater success in my } \\
\text { business. }\end{array}$ & $1(1.8)$ & $3(5.5)$ & $13(23.6)$ & $33(60.0)$ & $5(9.1)$ \\
\hline $\begin{array}{l}\text { My level of education has helped me adopt } \\
\text { certain strategies that enable my business gain } \\
\text { competitive advantage. }\end{array}$ & 2(3.6) & $2(3.6)$ & $10(18.2)$ & $21(38.2)$ & $20(36.4)$ \\
\hline
\end{tabular}

On whether SME firms are persuasive enough to reach out to greater number of customers, 24 $(43.6 \%)$ agreed and $5(9.1 \%)$ respondents strongly agreed. On whether SME firms success is based on the passion and confidence owners have in it, $21.8 \%$ of the respondents strongly agreed and 54.5\% respondents agreed. Meanwhile no respondent disagreed to this statement. When asked whether past experience has helped their businesses perform better, $34.5 \%$ agreed and $38.2 \%$ respondents strongly agreed. Thus, the majority of firms said past experience has helped them to correct mistakes from the previous work experience and made things better for their performance. However, for the least who disagreed said past experience does not really inspire their business career in the future.

With regards to whether having strong vision or being goal oriented has helped SMEs or guided them achieve greater success in their business, majority of $60 \%$ agreed and $9.1 \%$ strongly agreed. The above table indicates that, many SME firms are focused on moving forward, since they are always looking toward the future. These firms establish goals and will do all they can to attain the goals. To them, having strong vision helps propel them toward accomplishment and it guides their path to success.

In addition, when asked if educational level has helped the respondents to improve the performance level of their businesses, 3.6\% strongly disagreed, 3.6\% disagreed, $18.2 \%$ were neutral, $38.2 \%$ agreed and $36.4 \%$ strongly agreed. The least firms who disagreed believed that they did not need to be educated before they can run their businesses successfully, whereas others believed strongly that basic education certainly enhanced the overall quality of the business owner.

\section{Influence of Marketing Strategies on the Performance of SMEs}

Table 4.6: Marketing Strategies Influence on the Performance of SMEs

Does marketing strategies have any influence Frequency Percentage on the performance of your business?

\begin{tabular}{lrr}
\hline Yes & 34 & 61.8 \\
No & 21 & 38.2 \\
\hline
\end{tabular}

Respondents were asked whether their marketing strategies had any influence on the performance of their businesses, majority 34 (61.8\%) responded in the affirmative, whereas 21 
(38.2\%) said no. This implied that indeed the marketing strategies adopted by SME businesses impact their performance.

\section{Discussion}

\section{Influence of government policies and regulations on the performance of SMEs}

The findings indicate that the government is not really doing enough to support/help SMEs in the districts. It is notable that this finding contradicts what is known in the literature. For example, studies conducted by scholars such as; (Aryeetey \& Ahene, 2005; Kayanula \& Quartey, 2000; Ofosuaa et al., 2015; Ubabuko et al., 2010) have revealed that the governments in emerging economies have introduced reforms, created private sector advisory groups, and awarded automatic quotas for investors.

\section{Influence of access to finance on the performance of SMES}

Examining how access to credit influences the performance of SMEs, the findings indicated that many firms are of the view that access to finance had aided their businesses acquire raw materials for operation (Opoku-Afriyie, 2019). Equally, SMEs are able to acquire modern technologies which affect their production positively due to access to finance. Finally, many firms were not of the view that access to finance has helped their business expand due to adoption of new strategies. All the above results are in sharp contrast to scholars (Koráb \& Poměnková, 2015; Maziriri \& Chivandi, 2020; Punyasavatsut, 2011; Rand et al., 2011).

\section{Influence of availability of business information service on SMEs performance}

The findings of this research point out that many of the SME firms had used business information to devise better strategies for dealing with their competitors (Ngetich \& Kithae, 2020). Many managers/owners of the businesses also agreed that business information has helped them identified potential customers and developed a business relationship with them (Aziz \& Mahmood, 2011). Many firms again agreed that business information has aided in decision-making. To these businesses, information on their strengths, weaknesses, opportunities and threats have helped them to identify the internal and external position of their businesses (Indris \& Primiana, 2015).

\section{Influence of entrepreneurs characteristics on the performance of SMEs}

In looking at the effects of entrepreneurs' characteristics on SMEs performance, many of the owners said being persuasive in the business has helped them reach greater number of customers. Consequently, this has increased their sales for the previous four months (Storey, 2011). Additionally, majority of firms agreed that due to the passion and confidence they have in their businesses, they are able to run the business successfully without difficulty (Roland, Zamberi, Mohd, \& Yusof, 2012). With regard to past experience, the study revealed that their businesses have been helped to perform better than previously as their previous knowledge directs them in what to do and what not to (Barreira, 2004; Peña, 2002; West \& Noel, 2009). The findings again revealed that most businesses have been able to achieve greater successes because of the strong vision they have (D'Amboise, 2000). Finally, majority of firms were able to adopt strategies that helped them to gain competitive advantage over their competitors due to their educational level (Neneh, 2011). However, the few who disagreed that the level of education might not be a panacea for them to develop better strategies to gain competitive advantage could be right because with or without educational background, their businesses might have survived (Peters \& Brijlal, 2011). 


\section{Influence of marketing strategies on the performance of SMEs}

The study revealed that the marketing strategies adopted by SME businesses truly impact their performance. This was evident when majority of businesses responded positively to the statement that the marketing strategies adopted had strong impact on the performance of their businesses. This finding is supported by scholars such as; Amin, (2021); Finoti et al. (2017); and Tang et al. (2007) who concluded that marketing strategies impacted SMEs performance positively.

\section{Conclusions and Recommendations}

The study identified various factors that impact the business performance of SMEs in Ghana, an emerging market economy. These influencing factors were; the influences of government policies and regulations, access to credit, availability of business information service, the entrepreneurs' features and marketing strategies and their impact on the performance of SMEs.

Besides, it was found that access to credit aids SMEs' businesses in the acquisition of raw materials for operation and businesses are able to pay their workers due to access to finance. However, access to credit was equally a great constraint to the SMEs performance and their overall contribution to the economic growth of Ghana's economy. Also, the findings indicate that government is not really doing enough to support SMEs. It is therefore, recommended that the local assemblies and the government of Ghana should put in place measures like making grants and loans readily accessible to these SMEs. Again, the study revealed that for SMEs to perform well, a lot depends on individual entrepreneurs' characteristics such as; level of education, past experiences in business, the ability to persuade, be creative, and have strong vision, passion and confidence in their businesses and this will certainly guide them in their endeavours. Moreover, the study discovered that marketing strategies adopted by SME businesses rightly impact their performance. Furthermore, the study supports the academic literature on business performance of SMEs. Consequently, the study is important to future investigators who may want to use it as a reference document and also as basis for advancing their arguments.

It is hoped that the study's findings will enable policy makers and governments to design pragmatic policies that will support the SMEs and improve the business performance of the SMEs in developing economies. In addition, development partners can use this study's results to devise policies and actions to help improve the performance of SMEs in emerging market economies. Again, the government of Ghana should acknowledge SMEs contributions and involve them in its decisions and structure ways to support the firms to grow and perform adequately. Also, for many SMEs to perform well, a lot depends on their individual characteristics especially their level of education, ability to persuade, be creative, and have a strong vision and use of past experiences in their activities. It is thus, recommended that the government of Ghana should help them to improve their knowledge and skills. The SMEs themselves should develop new ideas to fulfill their civil obligations such as the payment of taxes. Finally, a periodic research or study should be done in Ghana to identify changes that may occur in SMEs performance. This will help put SMEs' on track.

\section{Limitations and Future Research}

This study is limited in terms of generalization of the results. This is because the study was carried out in Kwahu Municipalities in the Eastern Region of Ghana without considering the other 15 regions in the country. Therefore, it will not be prudent to generalize the results. What is more, the sample size of fifty-five SMEs' leaves much to be desired. It is our fervent hope 
that a future research should continue to examine other features that can improve on the performances of SMEs in developing countries while increasing the sample size.

\section{References}

Abisuga-oyekunle, O. A., Patra, S. K., \& Muchie, M. (2020). SMEs in sustainable development: Their role in poverty reduction and employment generation in sub-Saharan Africa. African Journal of Science, Technology, Innovation and Development, 12(4), 405-419.

Abor, J., \& Biekpe, N. (2007). Small Business Reliance on Bank Financing in Ghana. Emerging Markets Finance and Trade, 43(4), 93-102.

Abor, J., \& Quartey, P. (2010). Issues in SME development in Ghana and South Africa. International Research Journal of Finance and Economics, 39(39), 218-228.

Adeola, A. (2014). An Appraisal of ICT Adoption in Small and Medium Scale Enterprises in Nigeria. International Journal of Research, 1(8), 176-184.

Adongo, J. A., Atugeba, A. L. I., \& Insah, B. (2020). An assessment of the relationship between capital investments and financial performance of selected SMEs in the Upper East Region of Ghana. International Journal of Innovation and Applied Studies, 29(3), 760-110.

Afolabi, A. (2015). The effect of entrepreneurship on economy growth and development in Nigeria. International Journal of Development and Economic Sustainability, 3(2), 49-65.

Agyapong, F. O., Agyapong, A., \& Poku, K. (2017). Nexus between social capital and performance of micro and small firms in an emerging economy: The mediating role of innovation. Cogent Business \& Management, 4(1), 1-20.

Akorsu, P. K., \& Agyapong, D. (2012). Alternative model for financing SMEs in Ghana. International Journal of Arts and Commerce, 1(5), 136-148.

Amin, J. H. (2021). Influence of Marketing Strategies on the Performance of SMEs: Evidence from Abuja SMEs. Journal of Economics and Business, 4(1), 294-307.

Anigbogu, T. U., Onwuteaka, C. I., Edoko, T. D., \& Okoli, M. I. (2014). Roles of small and medium scale enterprises in community development: Evidence from Anambra South Senatorial Zone, Anambra State. International Journal of Academic Research in Business and Social Sciences, 4(8), 302-315.

Ansu-Mensah, P., Marfo, E.O., Awuah, L.S., \& Amoako, K.O. (2021). Corporate social responsibility and stakeholder engagement in Ghana's mining sector: a case study of Newmont Ahafo mines. International Journal of Corporate Social Responsibility, 6(1), 1-22.

Aryeetey, E., \& Ahene, A. A. (2005). Changing regulatory environment for small-medium size enterprises and their performance in Ghana. Centre on Regulation \& Competition: Working Paper Series No. 103, (16492016-135965).

Aziz, S. A., \& Mahmood, R. (2011). The relationship between business model and performance of manufacturing small and medium enterprises in Malaysia. African Journal of Business Management, 5(22), 8918-8932.

Barreira, J. C. D. (2004). The influence of business knowledge and work experience, as antecedents to entrepreneurial success. University of Pretoria.

Bhagwat, R., \& Sharma, M. K. (2007). Performance measurement of supply chain management: A balanced scorecard approach. Computers \& Industrial Engineering, 53, 43-62. https://doi.org/10.1016/j.cie.2007.04.001

Creswell, J. W. (2009). Research design: Qualitative, quantitative, and mixed methods approaches (3rd ed.). California: SAGE Publications Inc.

D’Amboise, G. (2000). Vision and Ojectives: A must for SMES in the new economy. Investigaciones Europeas de Dirección y Economía de La Empresa, 6(2), 57-64.

Domeher, D., Musah, G., \& Hassan, N. (2017). Inter-sectoral differences in the SME financing gap: Evidence from selected sectors in Ghana. Journal of African Business, 18(2), 194-220. https://doi.org/10.1080/15228916.2017.1265056

Dzisi, S., \& Ofosu, D. (2014). Marketing Strategies and the Performance of SMEs in Ghana. European Journal of Business and Management, 6(5), 102-111.

European Commission. (2003). Retrieved September 10, 2020, from User guide to the SME definition, Extract of Article 2 of the annex to Recommendation 2003/361/EC, website: https://ec.europa.eu/regional_policy/sources/conferences/state-aid/sme/smedefinitionguide_en.pdf

Finoti, L., Didonet, S. R., Toaldo, A. M., \& Martins, Tomas, S. (2017). The role of the marketing strategy process in the innovativeness- performance relationship of SMEs. Marketing Intelligence \& Planning, 35(3), 298315.

Ganbold, B. (2008). Improving access to finance for SME: International good experiences and lessons for Mongolia. Institute of Developing Economies, (438).

Ghana - Total Labor force. (2019). Retrieved October 10, 2020, from https://www.indexmundi.com/facts/ghana/ indicator/SL.TLF.TOTL.IN. 
Gunawan, T., Jacob, J., \& Duysters, G. (2016). Network ties and entrepreneurial orientation: Innovative performance of SMEs in a developing country. International Entrepreneurship Management Journal, 12, 575-599.

Herr, H., \& Nettekoven, Z. M. (2018). The role of small and medium-sized enterprises in development: What can be learned from the German experience? Global Labour University Working Paper, (53), 32.

Ibrahim, M. I., \& Mustapha, B. (2019). Determinants of small and medium enterprises performance in Nigeria: The role of government support policy. International Journal of Business and Economics Research, 8(2), 41-49.

Indris, S., \& Primiana, I. (2015). Internal and External Environment Analysis on the Performance of Small and Medium Industries (Smes) in Indonesia. International Journal of Scientific \& Technology Research, 4(04), 188-193.

Islam, A. M., Khan, M. ., Obaidullah, A. Z. M., \& Alam, S. (2011). Effect of Entrepreneur and Firm Characteristics on the Business Success of Small and Medium Enterprises (SMEs) in Bangladesh. International Journal of Business and Management, 6(3), 289-299. https://doi.org/10.5539/ijbm.v6n3p289

Kauffmann, C. (2005). Financing SMEs in Africa, OECD Development Centre Policy Insights No. 7. African Economic Outlook 2004/2005, a Joint Publication of the African Development Bank and the OECD Development Centre, (7).

Kayanula, D., \& Quartey, P. (2000). The policy environment for promoting small and medium-sized enterprises in Ghana and Malawi. Institute of Development Policy Management (IDPM), University of Manchester: Manchester, UK.

Keh, H. T., Nguyen, T. T., \& Ng, P. H. (2007). The effects of entrepreneurial orientation and marketing information on the performance of SMEs. Journal of Business Venturing, 22, 592-611. https://doi.org/10.1016/j.jbusvent.2006.05.003

Keskin, H., Sentürk, C., Sungur, O., \& Kiris, H. M. (2010). The importance of SMEs in developing economies. 2nd International Symposium on Sustainable Development, (June), 183-192.

Khan, M. A., Siddique, A., Sarwar, Z., Huong, L. T. M., \& Nadeem, Q. (2020). Determinants of entrepreneurial small and medium enterprises performance with the interaction effect of commercial loans. Asia Pacific Journal of Innovation and Entrepreneurship, 14(2), 161-173.

Koráb, P., \& Poměnková, J. (2015). Access to Credit of SMEs in the Czech Republic During the Financial Crisis and in the Post-crisis Period. Acta Universitatis Agriculturae et Silviculturae Mendelianae Brunensis, 63(4), 1297-1302.

Lange, T., Ottens, M., \& Taylor, A. (2000). SMEs and barriers to skills development: a Scottish perspective. Journal of European Industrial Training, 24(1), 5-11.

Laurenţiu, R. M. (2016). Importance of SMEs in European countries economy. Annals of the "Constantin Brâncuşi" University of Târgu Jiu, Economy Series, 1(3), 174-177.

Leavy, P. (2017). Research Design: Quantitative, Mixed Methods, Arts-Based, and Community-Based Participatory Research Approaches. New York: The Guilford Press.

Matovu, B. H. (2011). Perceived quality of accounting information and performance of Small and Medium Enterprises. (Doctoral dissertation), Makerere University.

Maziriri, E. T., \& Chivandi, A. (2020). Modelling key predictors that stimulate the entrepreneurial performance of small and medium-sized enterprises (SMEs) and poverty reduction: Perspectives from SME managers in an emerging economy. Acta Commercii - Independent Research Journal in the Management Sciences, $20(1), 1-15$.

Mutandwa, E., Taremwa, N. K., \& Tubanambazi, T. (2015b). Determinants of business performance of small and medium size enterprises in Rwanda. Journal of Developmental Entrepreneurship, 20(1), 1-12.

Muzenda, A. (2014). A conceptual model of the determinants of performance of tourism sector small and medium enterprises ( SMEs ). International Journal of Business and Management Invention, 3(1), 30-35.

Mwihaki, K. I. (2015). Factors influencing performance of small and medium enterprise tea firms in Mombasa County, Kenya. University of Nairobi.

Neely, A. (2002). Business performance measurement: Theory and practice. Cambridge University Press.

Neely, A., \& Austin, R. (2004). Business performance measurement: Theory and practice. Cambridge University Press.

Neneh, B. N. (2011). The impact of entrepreneurial characteristics and business practices on the long term survival of small and medium enterprises (SMEs). University of the Free State.

Ngetich, B., \& Kithae, P. P. (2020). Access to business information, business finance, managerial skills and performance of SMES in Kenya. International Journal of Management and Leadership Studies, 2(1), 7077.

Nunkoo, R., Teeroovengadum, V., Seetanah, B., Sannasee, R., \& Pooloo, A. (2020). Determinants of tourism small and medium enterprises financial performance. Development Southern Africa, 37(5), 809-824. 
Ofosuaa, B., Duku, M. O., Asante, R. B., \& Dorgbley, P. K. (2015). Role of Small and Medium-Scale Enterprises in the Economic Development of Ghana (Perception of Entrepreneurs in the Accra Metropolis). Kwame Nkrumah University of Science \& Technology.

Ojo, A., Akinsunmi, S., \& Oluwatimilehin, O. (2015). Influence of Business Information Use on Sales Performance of SMEs in Lagos State. Library Philosophy and Practice (e-Journal), 1208.

Opoku-Afriyie, P. (2019). Inter-Sectoral Key Success Factors of Small and Medium Scale Enterprises in Ghana. Journal of Economics and Business, 2(3), 951-963.

Otero, L. E., Gallego, P. A., \& Pratt, R. M. (2014). Click-and-Mortar SMEs: Attracting customers to your website. Business Horizons, 57(6), 729-736.

Oyedele, O. M., Oluseyi, O., Olalekan, A., Kabuoh, M., \& Elemo, G. N. (2014). On Entrepreneurial Success of Small and Medium Enterprises (SMEs): A Conceptual and Theoretical Framework. Journal of Economics and Sustainable Development, 5(16), 14-24.

Parry, S., Jones, R., Rowley, J., \& Beata, K. T. (2012). Marketing for survival: A comparative case study of SME software firms. Journal of Small Business and Enterprise, 19(4), 712-728. https://doi.org/10.1108/14626001211277488

Pena, I. (2004). Business incubation centers and new firm growth in the Basque country. Small Business Economics, 22, 223-236.

Peña, I. (2002). Intellectual capital and business start-up success. Journal of Intellectual Capital, 3(2), 180-198. https://doi.org/10.1108/14691930210424761

Peris, S. F., Supian, K., Hasanat, M. W., \& Hossain, M. N. (2020). A mediating effect of green market orientation on the environmental performance: From a literature review to a conceptual framework. Journal of Management Info, 7(2), 92-118.

Peters, R. M., \& Brijlal, P. (2011). The relationship between levels of education of entrepreneurs and their business success: A study of the province of KwaZulu-Natal, South Africa. Industry \& Higher Education, 25(4), $265-275$.

Philip, M. (2010). Factors affecting business success of small \& medium enterprises (SMEs). Amity Global Business Review, 1(2), 118-136.

Punyasavatsut, C. (2011). SME Access to Finance in Thailand. In in Harvie, C., S. Oum, and D. Narjoko (eds.), Small and Medium Enterprises (SMEs) Access to Finance in Selected East Asian Economies (pp. 193-230). Jakarta: ERIA Research Project Report 2010-14.

Rand, J., Tarp, F., Tien, T., \& Nguyen, T. T. (2011). SME Access to Credit. Munich Personal RePEc Archive, (29467).

Rasoli, A., \& Mirza, A. (2019). Financing small and medium enterprises in Afghanistan. Kardan Journal of Economics and Management Sciences, 2(4), 97-111.

Roland, S., Zamberi, S., Mohd, L. N., \& Yusof, M. (2012). Women Entrepreneurs: Making a change from Employment to Small and Medium Business Ownership. Procedia Economics and Finance, 4, 321-334. https://doi.org/10.1016/S2212-5671(12)00347-4

Sarbah, A., \& Wen, X. (2014). Corporate governance practices in Ghanaian family businesses: A conceptual framework. International Journal of Advancements in Research \& Technology, 3(1), 100-115.

Setsoafia, E. D., Sarpong, D. B., \& Kwadzo, G. T. M. (2013). Determinants of direct marketing strategy adoption by agro SMEs' in the Greater Accra Region, Ghana. Asian Journal of Agricultural Extension, Economics \& Sociology, 2(2), 105-117.

Širec, K., \& Močnik, D. (2010). How entrepreneurs' personal characteristics affect SME's Growth. Our Economy (Nase Gospodarstvo), 56(1-2), 3-12.

Smirat, B. (2013). The use of Accounting Information by Small and Medium Enterprises in South District of Jordan, ( An empirical study ). Research Journal of Finance and Accounting, 4(6), 169-175.

Storey, D. J. (2011). Optimism and chance: The elephants in the entrepreneurship room. International Small Business Journal, 29(4), 303-321.

Tang, Y., Wang, P., \& Zhang, Y. (2007). Marketing and business performance of construction SMEs in China. Journal of Business \& Industrial Marketing, 22(2), 118-125. https://doi.org/10.1108/08858620710730230

Ubabuko, K., Kavuwo, H. A., \& Adjei, E. K. (2010). Analysis of the SME sector in Tanzania and Ghana. Gotland University.

Vettriselvan, R., \& Sathya, M. (2018). Social inclusion at Indian small and medium mechanical engineering enterprises. International Journal of Mechanical Engineering and Technology, 9(8), 749-757.

Vuolle, M. (2011). Measuring Performance Impacts of Mobile Business Services from the Customer Perspective. Tampere University of Technology.

West, G. P., \& Noel, T. W. (2009). The impact of knowledge resources on new venture performance. Journal of Small Business Management, 47(1), 1-22.

Wilson, R. M. S., \& Gilligan, C. (2005). Strategic Marketing Management (3rd ed.). Abingdon, UK: Routledge. 
World Population Review. (2019). Retrieved October 10, 2020, from https://worldpopulationreview.com/countries/ghana-population/.

Xavier, J. A., \& Gomez, E. T. (2018). Still an ethnic enterprise after a generational change? Indian-owned SMEs in Malaysia. Journal of Southeast Asian Studies, 49(2), 297-322.

Yang, Y. F., \& Islam, M. (2012). The influence of transformational leadership on job satisfaction: The balanced scorecard perspective. Journal of Accounting \& Organizational Change, 8(3), 386-402. https://doi.org/10.1108/18325911211258353

Zdraveski, D., Janeska, M., Sotiroski, K., \& Kukunoski, A. I. (2018). Importance and use of information technology in SMEs in Macedonia-Case of Pelagonia Region. In IBANESS Conference SeriesPrilep/Republic of Macedonia, (September), 1-10. 